ELORE (ISSN 1456-3010), vol. $18-2 / 2011$.

Julkaisija: Suomen Kansantietouden Tutkijain Seura ry.

[http://www.elore.fi/arkisto/2_11/utriainen.pdf]

KIRJA-ARVIO

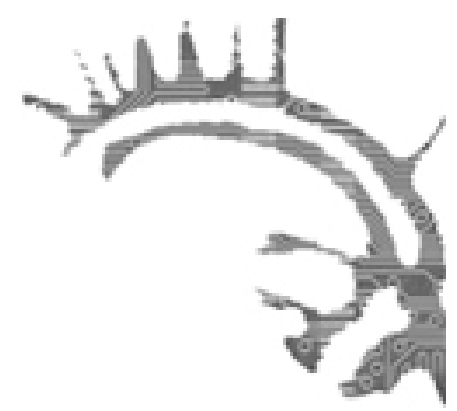

\title{
KUOLEMA LUTERILAISEN KIRKON NURKAN TAKANA
}

KOSKI, KAARINA 2011: Kuoleman voimat. Kirkonväki suomalaisessa uskomusperinteessä. Helsinki: SKS. 371 sivua.

\section{Terhi Utriainen}

Kaarina Kosken väitöskirja Kuoleman voimat on vankkaa perustutkimusta ja hyvin etenevää kerrontaa kuoleman voimasta ja väestä pääosin Suomalaisen Kirjallisuuden Seuran arkistoon tallentuneessa länsisuomalaisessa arkistomateriaalissa. Työ kiinnittyy kriittisiin keskusteluihin folkloristiikan peruskysymyksistä, kuten perinnelajianalyysin rajoista sekä kerääjistä, arkistoista ja tutkijoista tutkimusta suuntaavien kategorioiden rakentajina. Se kuitenkin pitää myös visusti kiinni siitä monimerkityksisestä ja jännitteisestä todellisuudesta, jota kaikki tämä jollain tavoin yrittää kuvata tai jäsentää. Katsaukseni Kosken teokseen ei pureudu niinkään folkloristisiin hienosäätöihin kuin työn antiin ikkunoiden avaajana kuolemankulttuurin ja kansanomaisen uskonnollisuuden maisemiin ja tutkimukseen.

\section{LÄNSISUOMALAINEN KUOLEMANKERRONTA}

Kuoleman ja elämän tai kuolevien ja elävien välillä on kaikkina aikoina ja kaikissa kulttuureissa olemassa jonkinlainen vaihtosuhde, jonka järjestämiseen ja esittämiseen voidaan käyttää erilaisia keinoja. Kosken työ purkaa yhden tätä vaihtoa kuvaavan aineiston osiinsa ja jäsentelee sen kautta näkymän yhteen kiinnostavaan suomalaiseen ajanjaksoon. Työ myös korjaa suomalaisen kuolemankulttuurin tutkimuksen painopistettä tärkeällä tavalla; onhan läntistä kuolemanperinnettä tutkittu huomattavasti paljon vähemmän kuin itäistä.

Kosken perinpohjainen ja laaja selvitys täsmentyy metodologisesti siihen monikehyksiseen kertomuksellisunteen, jonka aiheena ovat kuolemaan liittyvät käsitykset ja 
Terhi Utriainen: Kuolema luterilaisen kirkon nurkan takana

kuvaukset. Työ suo kuitenkin paljon tilaa narratiivisten välineiden mahdollisuuksien kartoituksen ohella myös niiden suhteille kokemuksiin ja sosiaaliseen todellisuuteen. Huomiota saavat sekä kerronnan erilaisten rajojen koettelu että kertojien eletty arki ja sen uskonnolliset, maailmankuvalliset ja sosiaalipoliittiset reunaehdot. Olemme tekemisissä yleisinhimillisten kysymysten (kuolema, toiseus, tuonpuolinen) ja niiden tietyn ajallis-paikallisen artikulaation palasten kanssa. Esimerkiksi nykyisten populaarielokuvien zombit haarukoivat jossain määrin samoja kysymyksiä kuin länsi- ja pohjoissuomalainen kirkonväki - ja toisaalta ne toimivat monessa mielessä toisenlaisessa maailmassa ja toisenlaisten esityksellisten ja uskomuksellisten resurssien varassa.

\section{LUTERILAINEN KIRKKO JA KUOLEMA HÄIRIÖNÄ}

Kertomukset eri syistä paikaltaan lähtevästä kirkonväestä kuuluvat siihen ristiriitaiseen aikaan, jolloin kuolema vielä tapahtui ja hoidettiin kodin piirissä mutta jossa luterilainen normisto oli tehnyt kuoleman kanssa toimimisesta tabun. Luterilainen kirkko yhtäältä toi kuolleet konkreettisesti omalle pihalleen, kirkkomaalle - ja toisaalta kuolleiden ja kuoleman kanssa ei oikeastaan olisi pitänyt lainkaan askaroida. Lisää jännitettä syntyi siitä, että käytännön kansauskossa kuolleet olivat jatkuvasti tärkeitä. (Ja ovat itse asiassa vieläkin: esimerkiksi brittiläisen uskontososiologi Abby Dayn [2011] tutkimus osoittaa, että suuri osa tämän päivän englantilaisista kokee vahvan yhteyden kuolleisiin lähiomaisiin. Tämä kysymys ansaitsisi ehdottomasti lisää tutkimusta.) Luterilaisuuden ja kansanuskon jännitteet ja ristiriidat ovat saaneet purkautumisteitä kertomuksissa kalmasta, kirkonväestä ja muista paikaltaan lähteneen kuoleman voimista. Samalla sävyltään ja funktioltaan erilaiset kertomukset ovat tuottaneet jännitteiseen tilanteeseen luovia ja joskus jopa karnevalistisia ratkaisuja.

Kosken työssä tutkittuja kuoleman ilmentymiä yhdistää se, että niissä on keskeisesti mukana kuva kuolemasta häiriönä ja epätasapainotilana, josta erilaisin keinoin pyritään eroon ja jota vasten elävien (yhteisön) on erottauduttava ja vahvistettava itseään. Koska kuolema tai kalma kuitenkin pohjimmiltaan on ambivalentti ja monikäyttöinen voima, se saatetaan myös valjastaa erilaisten asioiden hoitamiseksi, esimerkiksi parantamisen tai kostamisen välineeksi. Tällä ihmisten aktiivisella lähestymisellä on suuret riskinsä, ja siksi siihen ryhtyvien on hallittava sekä omat voimansa että toisen maailman manipuloimisen keinot. Toiminta kuoleman kanssa on taitolaji.

Kosken analyysissä kirkonväen kategorian sisältö jätetään avoimeksi ja liikkuvaksi, mitä kuvastavat monet päällekkäiset tai vähintäänkin toisiaan lähelle tulevat nimitykset kuten maahiset, kummitukset, kalma, piru, tyhjät, jopa keijukaiset ja pikku-ukot. Joskus tietyt merkitykset vakiintuvat paikallisesti tai kertojakohtaisesti. Koski käsittelee tätä avointa luokkaa prototyyppien kautta ja nostaa sellaisiksi vainajien joukon, omaehtoisesti liikkuvan väen sekä voimankaltaisen väen. Arkistomateriaalia siis lähestytään avoimena puhuntana, kuten kieltäkin nykyisin monesti tarkastellaan.

Työ kiteyttää kuoleman voimista kertovat lajit etäisten ja läheisten kertomusmaailmoiden jatkumolle. Etäisimmät kertomukset, jotka eivät suoraan liiku kertojan omassa arkimaailmassa, kuvaavat kuoleman ja kuolleet sekä niihin liittyvät tapahtumat toisin 
Terhi Utriainen: Kuolema luterilaisen kirkon nurkan takana

kuin lähemmäs kokijan oman arjen todellisuutta tuodut. Etäisen ja läheisen kertomusmaailman jännitteellä muuttuu moni asia, esimerkiksi se millaisina hahmoina kuolleet havaitaan. Lähelle tuoduissa tarinoissa, jotka voidaan esittää kertojalle itsellekin tapahtuneiksi, kyse on usein vain epämääräisestä havainnosta tai aavistuksesta (hajusta tai usvanomaisesta liikkeestä). Sen sijaan etäälle viedyissä tarinoissa (kuten öiseen kirkkoon tai kirkkomaalle sijoittuvissa) kuolleet esitetään konkreettisina yksilöllisinä hahmoina, jotka voivat jopa tarttua kiinni eläviin - tämä kuitenkin kerrotaan tapahtuvaksi lähinnä anonyymeille toisille kauan sitten tai kaukana kertojan arjesta.

\section{KuOLEMANPOLITIIKAT}

Kaiken kaikkiaan kirkonväki näyttäytyy yhtenä niistä historiallisesti ja kulttuurisesti vaihtelevista tavoista, jollaisena tuonpuoleinen ja tuntematon (näkymätön, toinen puoli tai toiseus) käsitetään ja jäsennetään suhteeseen tämänpuolisen kanssa. Silloin kun elävät ovat suhteen passiivisempi osapuoli, kontaktit ovat tapahtuneet ja jäsentyneet tarttumisena, pelotteluna ja pelästymisenä, säikäyttämisenä, tunkeutumisena, jne. Tuonpuoleisten voimien tarkoituksellinen hakeminen esimerkiksi parantamisen tai kostamisen välineeksi on edellyttänyt aktiivista koskettamista ja niiden pariin hakeutumista. Mitä tehtiin, riippui sekä siitä, kuinka etäälle tai lähelle viety kertomus on, että siitä, kuka esiintyy toimijana. Kaiken kaikkiaan Kosken tapa lukea materiaalia korostaa ihmisten aktiivista toimintaa sekä kertomusten sisältämissä kuvauksissa että kerronnan tapahtumassa. Kuoleman voimille ei vain alistuttu vaan niiden kanssa myös aktiivisesti toimittiin.

Koski käsittää kirkonväen hämärärajaiseksi negatiivisesti varautuneeksi kategoriaksi, joka on ollut isolta osalta luterilaisen valtauskonnon rakentama. Vaikka työ ei vallan teeman käsittelyyn syvennykään, kirkonväen kategorian sisällä huutaa historiallinen kysymys vallasta. Luterilainen kirkko halusi erottaa elävät kuolleistaan sen verran rajusti, että psykohistorioitsijat saattaisivatkin tulkita kirkonväen jopa separaatioahdistuksen purkautumisväyläksi ja post-koloniaalinen näkökulma löytäisi siitä alistumisen ja kapinan yhdistelmän! Kuoleman voimat -teoksen kaltaisen arkistotutkimuksen löydökset pohjustaisivat ja motivoisivat monenlaisia hedelmällisiä jatkoproblematisointeja ja teoretisointeja suomalaisen kuolemankulttuurin poliittista muodonmuutoksista niin mikro- kuin makrotasollakin.

\section{KirjallisuUs}

DAY, ABBY 2011: Believing in Belonging: Belief and Social Identity in the Modern World. Oxford: Oxford University Press.

Dosentti Terhi Utriainen toimii uskontotieteen yliopistonlehtorina Helsingin yliopistossa. 